\title{
Antimicrobial activity and chemical characterization of the bark decoction of cumaru stem
}

\author{
Maria Jaiana Gomes Ferreira ${ }^{1^{*}}$ (D) Patrícia Coelho do Nascimento Nogueira ${ }^{2}$ \\ Flayanna Gouveia Braga Dias ${ }^{1}$ Larissa Morais Ribeiro da Silva ${ }^{1}$ \\ Edilberto Rocha Silveira ${ }^{2}$ Evânia Altina Teixeira de Figueiredo ${ }^{1}$
}

${ }^{1}$ Departamento de Engenharia de Alimentos, Universidade Federal do Ceará (UFC), 60455-760, Fortaleza, CE, Brasil. E-mail: mjaiana@hotmail.com. ${ }^{*}$ Corresponding author.

${ }^{2}$ Departamento de Química, Universidade Federal do Ceará (UFC), Fortaleza, CE, Brasil.

ABSTRACT: The plant, Amburana cearensis A. C. Smith (Fabaceae), commonly called cumaru, is widespread in the Caatinga cearense, a less known ecosystem in Brazil. A. cearensis is rich in several compounds like protocatechuic acid, tannins, coumarin, flavonoids and phenolic heterosides, such as amburosides $A$ and $B$, that have been isolated. The aim of this study was to determine the antimicrobial potential and draw the chemical profile of the distinct characteristics of A. cearensis stem bark decoction, for its possible potential as a food conservation agent. The chemical compounds were characterized by one- and two-dimensional ${ }^{1} \mathrm{H}$ and ${ }^{13} \mathrm{C}$ NMR analyses and Liquid ChromatographyMass Spectrometry (LCMS). The compounds of coumarin, amburosides A and B, and glycosylated (Z)-o-coumaric acid. Using the plaque microdilution technique, the antimicrobial action was tested on Escherichia coli, Salmonella Enteritidis, Pseudomonas aeruginosa, Staphylococcus aureus and Listeria monocytogenes. The decoction demonstrated antimicrobial activity on Gram-positive bacteria. This was encouraging because natural antimicrobials are beneficial for food production, as they can inhibit the pathogenic microorganisms and boost the quality of hygiene and cleanliness.

Key words: bioactive compounds, microorganisms, natural antimicrobials.

Atividade antimicrobiana e caracterização química do decocto da casca do caule de cumaru

RESUMO: Amburana cearensis A. C. Smith (Fabaceae) é uma planta comum na Caatinga cearense, onde é popularmente conhecida como cumaru. Vários compostos têm sido isolados de A. cearensis, incluindo ácido protocatecúico, taninos, cumarina, flavonóides e heterosídeos fenólicos, como por exemplo os amburosídeos A e B. O objetivo desse estudo foi avaliar o potencial antimicrobiano e caracterizar o perfil químico do decocto da casca do caule de A. cearensis, visando a sua possível utilização na conservação de alimentos. A caracterização dos compostos químicos foi realizada pelas análises de RMN uni e bidimensionais de ${ }^{1} \mathrm{He}{ }^{13} \mathrm{C}$, e cromatografia líquida acoplada à espectrometria de massa. Foram identificados a cumarina, os amburosideos A e B, e o ácido (Z)-o-cumárico glicosilado. A atividade antimicrobiana foi realizada pela metodologia de microdiluição em placa sobre Escherichia coli, Salmonella Enteritidis, Pseudomonas aeruginosa, Staphylococcus aureus e Listeria monocytogenes. O decocto mostrou atividade antimicrobiana sobre bactérias Gram-positivas. Antimicrobianos naturais podem oferecer vantagens para a produção de alimentos, inibindo microorganismos patogênicos e melhorando a qualidade higiênico-sanitária. Palavras-chave: compostos bioativos, microorganismos, antimicrobianos naturais.

\section{INTRODUCTION}

The Fabaceae family, which includes the tree Amburana cearensis A. C. Smith (sin. Torresea cearensis), habitually grows in the northeastern caatinga, particularly in the state of Ceará, Brazil, commonly termed "cumaru", "imburana" or "smelling imburana". Famous for its stem bark, this tree finds extensive use in the preparation of "licks" in folk medicine, to effectively treat respiratoryrelated ailments like colds, bronchitis, flu and asthma. Seeds are often powdered and marketed as "imburana snuff', to induce sneezing and it is popular for its powerful and distinct coumarin odor, akin to the fragrance of vanilla (ALMEIDA et al., 2010).

Biologically active secondary metabolites occur plentifully in medicinal plants, and include the flavonoids, terpenoids, heterosides and alkaloids. The edaphoclimatic conditions, or environmental factors of climate, relief, temperature, humidity, soil type and rainfall affect their level of abundance. These categories of bioactive compounds are reported in a variety of plant part extracts, and are cited in the literature for their high antimicrobial 
potential, besides other characteristics, and are slowly garnering attention as a suitable substitute to reduce bacterial resistance to conventional drugs (FERNANDES et al., 2015).

Earlier, the phytochemical study of the cumaru stem bark enabled the isolation of secondary metabolites like protocatechic acid, vanillic acid, coumarin, amburosides $\mathrm{A}$ and $\mathrm{B}$, quercetin, isokaempferide, Kaempferol, 4'-methoxy-fisetina, Afrormosin, 3.4-dihydroxybenzoate of 6-coumaryl and 6-coumaryl protocatecuate (ALMEIDA et al., 2010). After the phytochemical study of the seeds, many other compounds, such as 6-hydroxycoumarin, $o$-coumaric acid, $p$-hydroxy-benzoic acid, the glycosylated $o$-coumaric acid isomers (E) and (Z), amburosides $\mathrm{CH}$ and 6-O-protocatechuic and coumarin were isolated (ALMEIDA et al., 2010; CANUTO et al., 2010).

There has been a rise in the amount of research done over the past recent years, on environmental issues and waste management in chemical processes. Aqueous extracts have emerged; therefore, as more environmentally viable substitutes because they do not produce any toxic waste, while at the same time, they also satisfy the norms of "green chemistry" (CUNHA et al., 2015). One more crucial use for them is the application of the aqueous extract to food substitutes as chemical preservatives, to satisfy consumer demands for healthy and microbiologically safe foods (SOUZA et al., 2005).

Due to the limited number of studies available in the literature on bioactive compounds, as well as the necessity for research which evaluates the antimicrobial potential of natural products, the present study was done to assess the antimicrobial potential and chemical characterization of the stem bark decoction of a wild species of $A$. cearensis.

\section{MATERIALS AND METHODS}

Plant collection was done in the municipality of Santa Quitéria / CE / Brazil (4³5'01.2”S 3948'02.4”W), during October 2014. All the analyses were done in the Laboratory of Phytochemical Analysis of Medicinal Plants LAFIPLAM and the Laboratory of Food Microbiology - LMA, both from the Federal University of Ceará.

Preparation of the stem bark decoction of a wild species of Amburana cearensis

To make the $A$. cearensis stem bark aqueous extract, $100 \mathrm{~g}$ of plant material was decocted in 500 $\mathrm{mL}$ of distilled water for $15 \mathrm{~min}$. Next, the aqueous solution thus produced was filtered and lyophilized to get Fraction 1 (5.37 g). The residual material drawn from this first extraction was then passed through a second extraction process, maintaining the identical conditions, to acquire Fraction $2(2.05 \mathrm{~g})$. Analysis was performed of both fractions via ${ }^{1} \mathrm{H}$ NMR and because both the spectra thus acquired were identical, and both could be used to produce the extract termed ACCC-DEC (7.42 g).

\section{Quantification of amburoside A and coumarin}

Using the $500 \mu \mathrm{g} . \mathrm{mL}^{-1}$ stock solutions of coumarin (AC-1) and amburoside A (AC-2) standards, the calibration curves were drawn. Six concentrations of $5,10,20,40,80$ and $160 \mu \mathrm{g} . \mathrm{mL}^{-1}$ were prepared from each stock solution.

Triplicate solutions were injected into a Shimadzu high performance liquid chromatograph, to produce each calibration curve. A Phenomenex LUNA C18 column $(250 \times 4.6 \mathrm{~mm}, 5 \mu \mathrm{m})$ was employed, at $35{ }^{\circ} \mathrm{C}$, maintaining a $1.0 \mathrm{~mL} \cdot \mathrm{min}^{-1}$ flow and using a $10 \mu \mathrm{L}$ loop. By visualization done at $260 \mathrm{~nm}$ wavelength, the chromatograms were acquired. The elution method involved a compound gradient of $\mathrm{H} 2 \mathrm{O}-\mathrm{H} 2 \mathrm{CO} 20.1 \%$, in the range of 25 $55 \% \mathrm{MeOH}$ for $15 \mathrm{~min}$, followed by $55-90 \%$ for $10 \mathrm{~min}$, and culminating with $90-100 \%$ for $5 \mathrm{~min}$. The aqueous ACCC-DEC extract was injected, in triplicate, during the same mobile phase, at 1.0 $\mathrm{mg} \cdot \mathrm{mL}^{-1}$ concentration.

The aqueous extract analyzed by Liquid chromatography-mass spectrometry (LCMS).

The ACCC-DEC was analyzed by LCMS also employing an ACQUITY UPLC (Waters) system coupled with a Quadrupole / Time-of-Flight Mass Spectrometry (QTOF, Waters) system. For the chromatographic runs, a Waters ACQUITY UPLC $\mathrm{BEH}$ column $(150 \times 2.1 \mathrm{~mm}, 1.7 \mu \mathrm{m})$ was used, maintaining the temperature fixed at $40^{\circ} \mathrm{C}$, a flow of $0.4 \mathrm{~mL}$. $\mathrm{min}^{-1}$ and an injection of $5 \mu \mathrm{L}$. Water was used as the mobile phase with $0.1 \%$ formic acid (A) and acetonitrile with $0.1 \%$ formic acid (B), in a gradient range of $2-95 \% \mathrm{~B}$ for $0-15 \mathrm{~min}$, and the remaining at $100 \% \mathrm{~B}$ from $15.1-17.0 \mathrm{~min}$, returning to $2 \% \mathrm{~B}$ from $17.1-19.1 \mathrm{~min}$.

The ionization technique employed ESI- in the 110-1180 Da range, with fixed source temperature maintained at $120^{\circ} \mathrm{C}$, desolvation temperature of 350 ${ }^{\circ} \mathrm{C}$, desolvation gas flow of $350 \mathrm{~L} . \mathrm{h}^{-1}$, extraction cone of $0.5 \mathrm{~V}$, capillary voltage of $2.6 \mathrm{kV}$ and leucineenkephalin as the lock mass. Masslynx 4.1 software (Waters Corporation) controlled the instrument. 
Minimum inhibitory concentration (MIC) and minimum bactericidal concentration $(M B C)$.

To prepare the inoculum, the strains of Salmonella Enteritidis IAL 1132, Pseudomonas aeruginosa IAL 1026, Escherichia coli ATCC 25922 and Staphylococcus aureus ATCC 27664 were cultivated on soybean tryptase agar - STA (Difco, Sparks, USA) the Listeria monocytogenes ATCC 19115, however, while cultivated on the same culture medium, was enriched with $0.1 \%$ yeast extract - STA + YE (Difco, Detroit, USA). All the inocula were then incubated at $35{ }^{\circ} \mathrm{C}$ for $24 \mathrm{~h}$ in BOD (Biochemical Oxygen Demand, Chimis / Model Q316-M26). Next, one colony was drawn from each microorganism and placed in tubes with $5 \mathrm{~mL}$ of the Soybean Tryptase Broth - STB (Difco, Sparks, USA). Incubation was performed at $35{ }^{\circ} \mathrm{C}$ for $24 \mathrm{~h}$, after which the final bacterial concentration of around $10^{8}$ CFU.mL ${ }^{-1}$ was acquired for each microorganism.

Evaluation of the antimicrobial activity of the aqueous extract on the growth of E. coli, S. Enteritidis, P. aeruginosa, S. aureus and $L$. monocytogenes was done using the plate microdilution technique (96 wells, $300 \mu \mathrm{L}$ capacity / well; Microtest TM, Becton Dickinson and Co.) (BRANEN \& DAVIDSON, 2004).

Analyses were done in triplicate under the tissue culture hood in the laminar flow cabinet, (Pachane / model 410). Serial dilutions of the bacterial concentration of $10^{8} \mathrm{CFU} . \mathrm{mL}^{-1}$ were then done, after which $100 \mu \mathrm{L}$ aliquots of the $10^{5} \mathrm{CFU}$. $\mathrm{mL}^{-1}$ bacterial suspension were poured into the microplate wells, plus $100 \mu \mathrm{L}$ of the antimicrobial solution diluted prior in water in concentrations varying from 3 to $19 \mathrm{mg} \cdot \mathrm{mL}^{-1}$. Three control wells were used, namely inoculum, culture medium and water (positive control) to assess the viability of the microorganism tested, as well as the wells filled with the culture medium and antimicrobial solutions at the concentrations investigated (control of the solutions) to confirm the safety of each solution. When the plate treatment distributions were completed, the initial optical density reading OD $630 \mathrm{~nm}(\mathrm{~T}=0)$ was recorded using an Elx 808 microplate absorbance reader (Instruments BioTek, Inc. Winooski, VT, USA). The next step was $24 \mathrm{~h}$ of incubation at 35 $\pm 1{ }^{\circ} \mathrm{C}$ within the appliance itself. The result was classified as an inhibitory concentration which was revealed as a variation $(\Delta)$ of the $630 \mathrm{~nm}$ readings $\leq$ 0.05 (BRANDT et al., 2010).

From each antimicrobial concentration tested a $100 \mu \mathrm{L}$ aliquot was drawn and spread on the spread plate surface with the STA medium evenly caoted. Plates were then subjected to incubation at $35^{\circ} \mathrm{C}$ for $24 \mathrm{~h}$.

The antimicrobial concentration tested, which caused, after three logarithmic cycles $\left(3.0 \log _{10}\right.$ CFU.mL $L^{-1}$ ) a reduction of the viable cells from the initial inoculum concentration $\left(10^{5}\right.$ CFU. $\left.\mathrm{mL}^{-1}\right)$, was idetified as the bactericidal (BRANDT et al., 2010; BRANEN \& DAVIDSON, 2004).

\section{RESULTS AND DISCUSSION}

Structural determination of compounds $A C-1$ and $A C-2$ The colorless crystals acquired from compound AC-1 were reported to be coumarin (Figure 1), which according to the literature was noted for its bronchodilatory, antinociceptive, antimalarial and antileishmania actions (CANUTO et al., 2014), justifying the use of cumaru treatment in disease treatment.

The pinkish amorphous solid obtained from compound AC-2 was recognized to be 4-O- $\beta$ D-glucopyranosyl benzyl protocatecuate, a phenolic glycoside also called amburoside A (Figure 2). Other authors have attributed active anti-inflammatory, antioxidant, hepatoprotective and antimalarial actions to this glycoside (CANUTO et al., 2014; LEAL et al., 2008).

\section{Calibration curve and standard quantification}

For both standards, the chromatographic method employed for HPLC elution was reported to be highly selective, permitting a good resolution between the peaks. From the LC-MS spectra the recognition of glycosylated (Z)-o-coumaric acid and Amburoside $\mathrm{B}$ was done, which were two other secondary metabolites (Figure 3).

In the aqueous extract ACCC-DEC, amburoside A was present in concentration of 2896.00 mg.100 g-1 extract or $221.56 \mathrm{mg} .100 \mathrm{~g}^{-1}$ plant. The coumarin was shown to be in concentrations of $1358.47 \mathrm{mg} .100 \mathrm{~g}^{-1}$ extract or $100.79 \mathrm{mg} .100 \mathrm{gg}^{-1}$ plant, confirming the effectiveness of this extraction method for both compounds.

\section{Antimicrobial activity}

The aqueous extract of Amburana cearensis stem bark revealed strong inhibitory and bactericidal action on L. monocytogenes $\left(15 \mathrm{mg} \cdot \mathrm{mL}^{-1}\right.$ and $\left.19 \mathrm{mg} \cdot \mathrm{mL}^{-1}\right)$ and $S$. aureus $\left(9 \mathrm{mg} \cdot \mathrm{mL}^{-1}\right.$ and 9 $\mathrm{mg} \cdot \mathrm{mL}^{-1}$ ), respectively, but with no effect upon the Gram-negative bacteria tested, most likely because their cellular constitution was more complex. This bacterial group investigated included the principal pathogens related to food-borne diseases. In their 


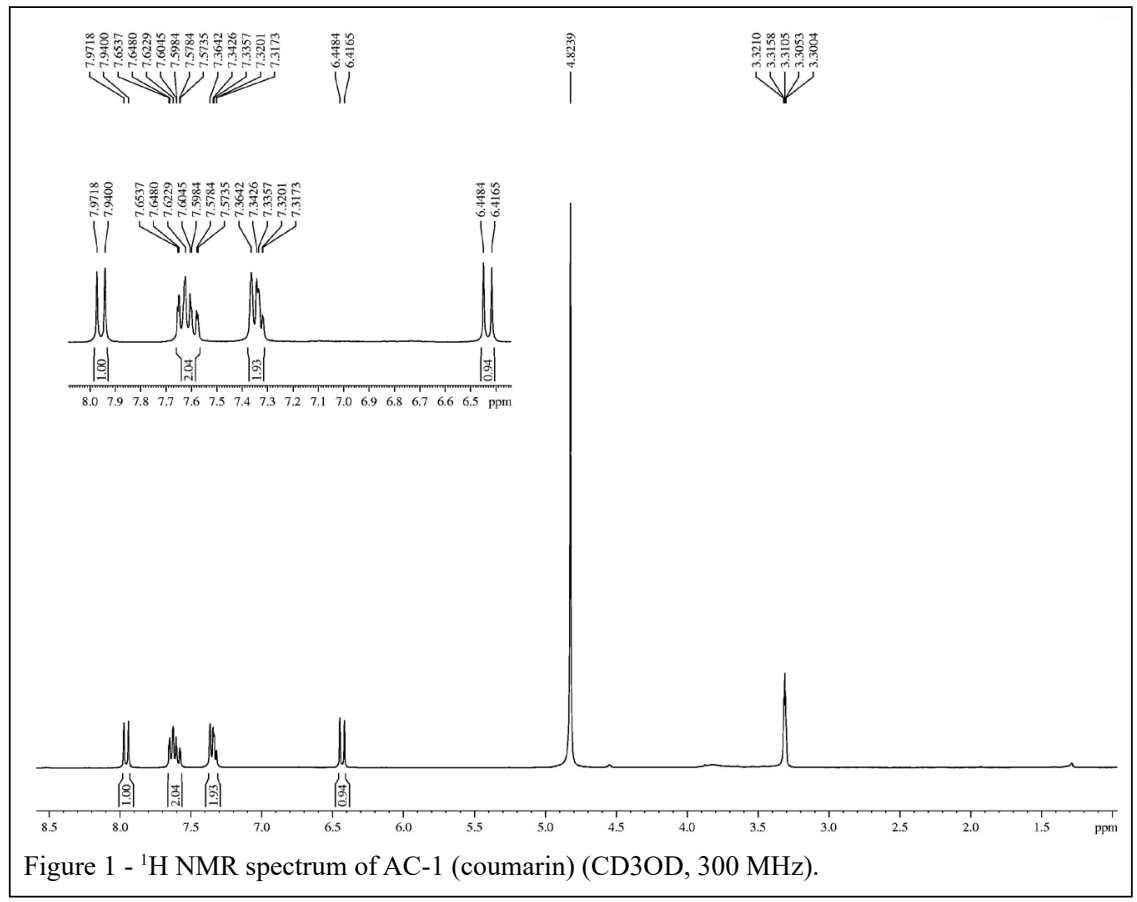

research, SILVA et al. (2012) clearly showed that the Caatinga plants, in low concentrations, exhibiting antimicrobial actions on gram-positive bacteria.

The current study demonstrated antimicrobial action only for the Gram-positive bacteria, but the researches by SÁ et al. (2011) and FERNANDES et al. (2015), through utilization of the ethanolic extract of $A$. cearensis stem bark, reported antimicrobial action on $E$. coli $\left(0.1667 \mathrm{mg} \cdot \mathrm{mL}^{-1}\right)$, Salmonella Enteretidis (0.1458 mg.mL $\left.\mathrm{m}^{-1}\right)$ and $S$.

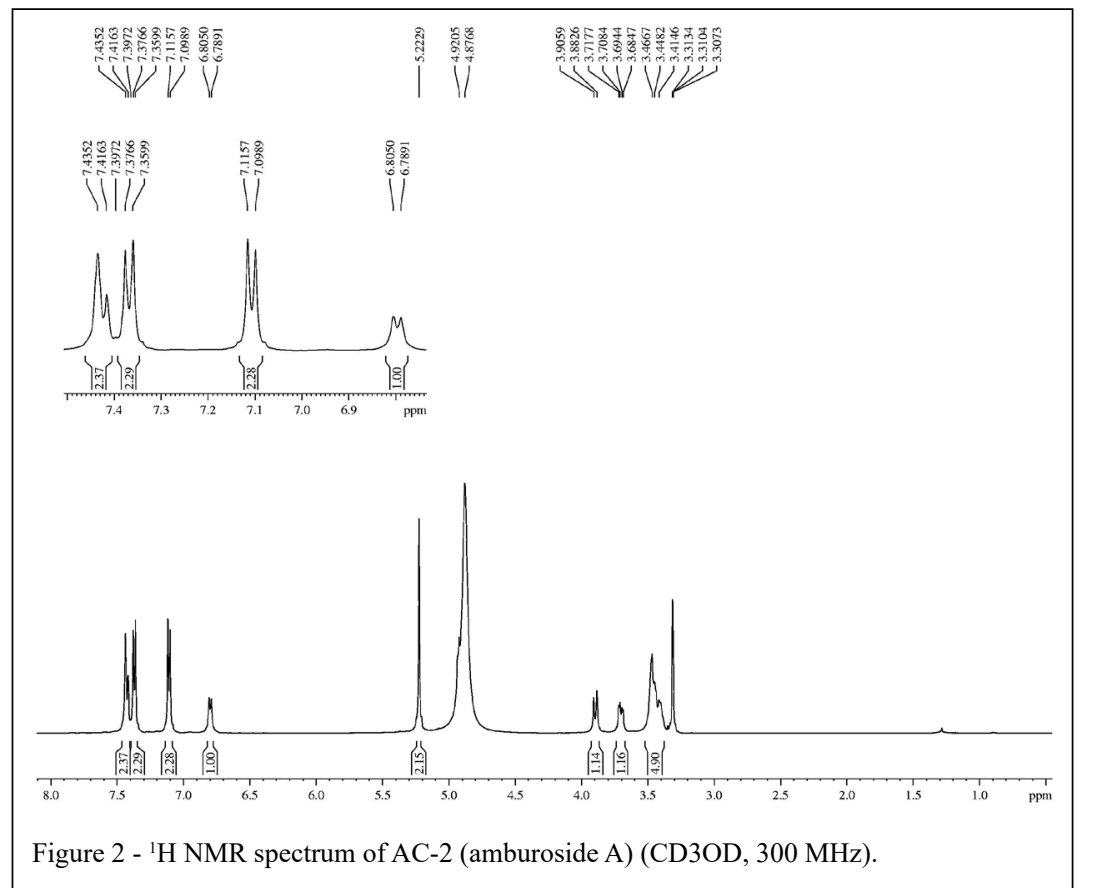

Ciência Rural, v.50, n.3, 2020. 


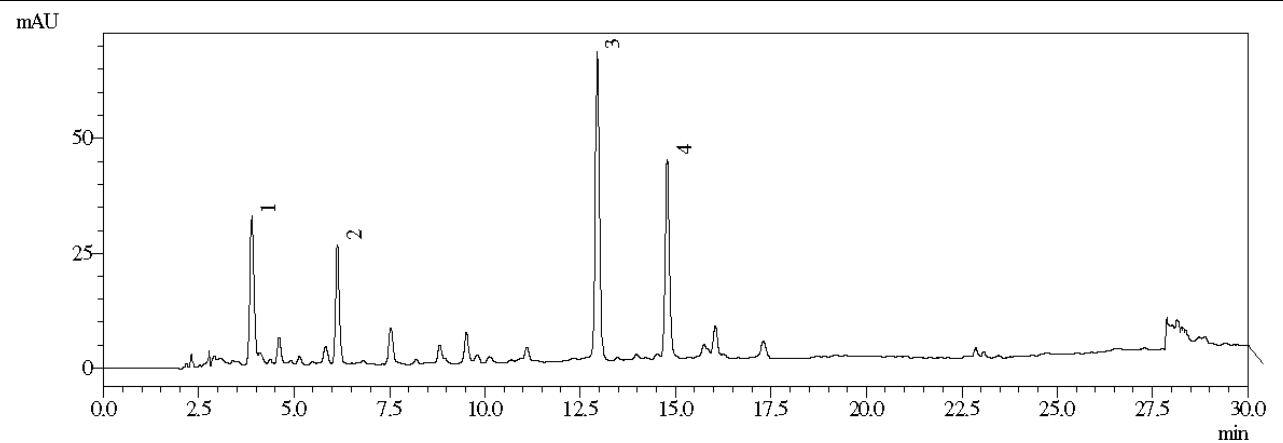

Figure 3 - Chromatogram of the aqueous extract of ACCC-DEC obtained by HPLC. Conditions: H2O-H2CO2 gradient $0.1 \% \mathrm{MeOH}$ of $25-55 \% \mathrm{MeOH}$ for $15 \mathrm{~min}$, followed by 55-90\% for $10 \mathrm{~min}$, ending with 90-100\% for $5 \mathrm{~min}$. Wavelength: $260 \mathrm{~nm}$. Glycosylated (Z) -o-coumaric acid (Peak 1), Amburoside B (Peak 2), Amburoside A (Peak 3) and coumarin (Peak 4).

aureus $\left(0.1458 \mathrm{mg} \cdot \mathrm{mL}^{-1}\right)$. They highlighted the fact that the ethanol used as a solvent during extract preparation may have released some compound possessing the capacity for antimicrobial action against Gram-negative bacteria and that it was the cellular composition of these bacteria which had hindered the antimicrobial action.

From the chemical characterization of the aqueous extract acquired from the $A$. cearensis stem bark decoction employed in this study, the presence of coumarin, glycosylated (Z)-o-coumaric acid and the amburosides A and B was noted. CANUTO et al. (2010) in their research also reported that coumarin and the phenolic glycosides (amburosides A and B) were present. Coumarins exhibiting antimicrobial activity has been reported prior in the literature.

In their research, BRAVO et al. (1999) isolated the coumarin from the dichloromethane extract of the stem bark giving evidence for the antimicrobial activity on $E$. coli and $S$. flexneri at a $0.1 \mathrm{mg} . \mathrm{mL}^{-1}$ concentration. They also demonstrated when another solvent was utilized to elaborate the extract, it supported the action on Gram-negative bacteria. MOSA et al. (2011) determined the antimicrobial activity of 4-hydroxy-coumarin-3thiocarbohydrazone and identified its efficacy on $P$. aeruginosa and $E$. coli at $0.1 \mathrm{mg} \cdot \mathrm{mL}^{-1}$ concentration, showing that the isolated and modified compound could act-up on the Gram-negative bacteria, an activity that was lacking when the $A$. cearensis stem bark decoction was used.

Although, many studies have not been conducted using strains isolated from foodstuffs, they strongly indicated that natural antimicrobials will be highly beneficial in the food sector, because through their capacity to inhibit the pathogenic microorganisms, they can help lengthen their lifespan, thus permitting products with nutritional value to find a place in the market (MOURA et al., 2013).

\section{CONCLUSION}

Amburoside A was reported in higher concentrations than coumarin in the $A$. cearensis stem bark decoction. During the quantification, besides the standards analyzed, the secondary metabolites of glycosylated and amburoside B (Z)-o-coumaric acid were identified.

In this study, the extract on evaluation displayed antimicrobial activity on Listeria monocytogenes and Staphylococcus aureus, significant pathogens persistently involved in food contamination.

\section{ACKNOWLEDGEMENTS}

The authors would like to thank the Fundação Cearense de Apoio ao Desenvolvimento Científico e Tecnológico (FUNCAP) and the Universidade Federal do Ceará (UFC).

\section{DECLARATION OF CONFLICT OF INTERESTS}

The authors declare no conflict of interest. The founding sponsors had no role in the design of the study; in the collection, analyses, or interpretation of data; in the writing of the manuscript, and in the decision to publish the results.

\section{AUTHORS' CONTRIBUTIONS}

All the authors have contributed equally to this manuscript. 


\section{REFERENCES}

ALMEIDA, J. R. G. S. et al. Amburana cearensis - a chemical and pharmacological review. Scientia Plena, v.6, n.11, p.1-8, 2010. Available from: <https://www.scientiaplena.org.br/sp/article/ view/106/65>. Accessed: Jul. 20, 2018.

BRANDT, A. L. et al. Inhibition of Listeria monocytogenes by food antimicrobials applied singly and in combination. Journal of Food Science, v.75, n.9, p.557-563, 2010. Available from: $<$ https:// doi.org/10.1111/j.1750-3841.2010.01843.x>. Accessed: Sept. 02, 2018. doi: 10.1111/j.1750-3841.2010.01843.x.

BRANEN, J. K.; DAVIDSON, P. M. Enhancement of nisin, lysozyme, and monolaurin antimicrobial activities by ethylenediaminetetraacetic acid and lactoferrin. International Journal of Food Microbiology, v.90, p.63-74, 2004. Available from: $<$ https://doi.org/10.1016/S0168-1605(03)00172-7>. Accessed: Aug. 20, 2018. doi: 10.1016/S0168-1605(03)00172-7.

BRAVO, J. A. et al. Bioactive phenolic glycosides from Amburana cearensis. Phytochemistry, v.50, p.71-74, 1999. Available from: $<$ https://doi.org/10.1016/S0031-9422(98)00497-X>. Accessed: Jun. 15, 2018. doi: 10.1016/S0031-9422(98)00497-X.

CANUTO, K. M. et al. Phytochemical study of cultured cumaru specimens (Amburana cearensis A. C. SMITH). Chemistry Nova, v.33, n.3, p.662-666, 2010. Available from: <http://doi. org/10.1590/S0100-40422010000300034>. Accessed: Dec. 01, 2018. doi: 10.1590/S0100-40422010000300034.

CANUTO, K. M. et al. Amburanins A and B from Amburana cearensis: Daphnodorin-type biflavonoids that modulate human neutrophil degranulation. Journal of the Brazilian Chemical Society, v.25, n.4, p.639-647, 2014. Available from: <http://doi. org/10.1590/S0100-40422010000300034>. Accessed: Jan. 02, 2019. doi: 10.1590/S0100-40422010000300034.

CUNHA, S. et al. Acetanilida: green synthesis without solvent. New chemistry, v.38, n.6, p.874-876, 2015. Available from: $<$ http://doi.org/10.5935/0100-4042.20150080>. Accessed: Oct. 29, 2018. doi: 10.5935/0100-4042.20150080.
FERNANDES, A. W. C. et al. In vitro antimicrobial activity of the caatinga biome plant extracts in porcine Escherichia coli isolates. Revista Brasileira de Plantas Medicinais, v.17, n.4, p.1097-1102, 2015. Available from: <http://doi.org/10.1590/1983-084x/14159>. Accessed: Oct. 22, 2018. doi: 10.1590/1983-084x/14159.

LEAL, L. K. A. M. et al. Protective effects of amburoside A, a phenol glucoside from Amburana cearensis, against $\mathrm{CCl}_{4}$-induced hepatotoxicity in rats. Planta Médica, v.74, p.497-502, 2008. Available from: $<$ http://dx.doi.org/10.1055/s-2008-1074501>. Accessed: Nov. 22, 2018. doi: 10.1055/s-2008-1074501.

MOSA, A. I. et al. Novel transition metal complexes of 4-hydroxycoumarin-3-thiocarbohydrazone: Pharmacodynamic of Co (III) on rats and antimicrobial activity. Spectrochimica Acta Part A: Molecular and Biomolecular Spectroscopy, v.81, p.35-43, 2011. Available from: <http://dx.doi.org/10.1016/j.saa.2011.05.035>. Accessed: Jun. 16, 2018. doi: 10.1016/j.saa.2011.05.035.

MOURA, F. M. L. et al. Utilization of caatinga biome plants to control pathogens of interest in the food area - a review. Acta Veterinaria Brasilica, v.7, n.2, p.125-136. 2013. Available from: $<$ https://doi.org/10.21708/avb.2013.7.2.3253>. Accessed: Sept. 03, 2018. doi: 10.21708/avb.2013.7.2.3253.

SÁ, M. C. A. et al. Antimicrobial activity of caatinga biome ethanolic plant extracts against gram negative and positive bacteria. Revista Brasileira de Ciência Veterinária, v.18, n.2/3, p.62-66, 2011. Available from: <http://dx.doi.org/10.4322/rbcv.2014.122>. Accessed: Dec. 03, 2018. doi: 10.4322/rbcv.2014.122.

SILVA, A. G. et al. Antimicrobial activity of medicinal plants of the caatinga (semi-arid) vegetation of NE Brazil. Current Topics in Phytochemistry, v.11, p.81-94, 2012. Available from: <http:// dx.doi.org/10.1016 / j.jep.2007.08.017>. Accessed: Jan. 05, 2019. doi: 10.1016/j.jep.2007.08.017.

SOUZA, E. L. et al. Antimicrobial effectiveness of spices: an approach for use in food conservation systems. Brazilian Archives of Biology and Technology, v.48, n.4, p.549-558, 2005. Available from: <http://dx.doi.org/10.1590/S151689132005000500007>. Accessed: Sept. 10, 2019. doi: 10.1590/ S1516-89132005000500007. 